\title{
MiR-206 functions as a tumor suppressor and directly targets K-Ras in human oral squamous cell carcinoma
}

This article was published in the following Dove Press journal:

OncoTargets and Therapy

II September 2014

Number of times this article has been viewed

\section{Feiou Lin' \\ Linjie Yao ${ }^{2}$ \\ Jin $\mathrm{Xiao}^{3}$ \\ DengFeng Liu $^{3}$ \\ Zhenyu $\mathrm{Ni}^{\prime}$}

'Department of Orthodontics, 2Department of Pedodontics, ${ }^{3}$ Department of Oral and Maxillofacial Surgery, School and Hospital of Stomatology, Wenzhou Medical University, Wenzhou, People's

Republic of China
Purpose: MicroRNA-206 (miR-206) has been proven to con regulated in many hum

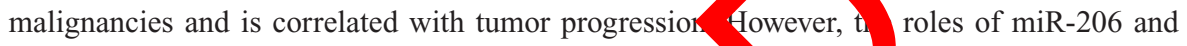
its related molecular mechanisms in oral squamoy cell co inoma SCC) are still unclear. Thus, the aim of this study was to explore the ects of yiR-2 OSCC tumorigenesis and development.

Methods: Quantitative real-time polyme chain action as used to detect miR-206 expression in OSCC cell lines and primary t ron sues. The sociation of miR-206 expression with clinicopathological factors and proonosis was a analyzed. In addition, the effects of miR-206 on the biological behavior of 0 SCC cells were nvestigated. Lastly, the potential regulatory function of miR-206 on K-R expressio was confirmed.

Results: MiR-206 expression vas signi cantly downregulated in OSCC tissue samples and cell lines (both $P<$ Decreasur miR-206 expression was significantly associated with advanced tumor node eta AS of the prim? or), $\mathrm{p}$ itive $\mathrm{N}$ classification (ie, spread to regional lymph nodes), and shorter overall rvival. 1 additi , upregulation of miR-206 in Tca8113 cells was able to reduce cell prol rat wasion, and migration and promote cell apoptosis in vitro. Further, K-Ras was firmed as direct target of miR-206 by using luciferase reporter assay.

Con 'usion: These findings indicate that miR-206 may act as a tumor suppressor in OSCC and cous. serve as a novel therapeutic agent for miR-based therapy.

Keywords: miR-206, oral squamous cell carcinoma, prognosis, proliferation, apoptosis, inva on

\section{Introduction}

Oral squamous cell carcinoma (OSCC) is the most common malignant neoplasm of the oral cavity and represents about $90 \%$ of all oral malignancies. ${ }^{1}$ Despite recent advances in multimodality treatments, more than $50 \%$ of OSCC patients experience relapse, including local recurrence, regional lymph node metastasis, and distant spread. The 5-year overall survival rate in OSCC is less than 50\%, which has not significantly increased in the last three decades. ${ }^{2}$ Previous studies have demonstrated diverse genetic alterations in OSCC, ${ }^{3,4}$ but the highly complex molecular mechanisms underlying OSCC carcinogenesis and progression remain obscure. Therefore, it is necessary to search for novel markers for OSCC that can accurately identify biological characteristics of tumors, improve therapeutic strategies, and predict clinical outcome.

MicroRNAs (miRs) are a class of naturally occurring small (21-25 nucleotides) noncoding RNAs. They bind through partial sequence homology to the 3 ' untranslated
Correspondence: Zhenyu Ni

Department of Orthodontics, School and Hospital of Stomatology, Wenzhou Medical University, I I3, Xue Yuan West Road, Lu Cheng Distriction, Wenzhou, People's Republic of China

Tel +8657788063012

Fax +8657788063666

Email manunizy@163.com 
region of target messenger RNAs and either block translation or promote messenger RNA degradation. ${ }^{5,6}$ Beyond their involvement in diverse biological processes, including cell growth, apoptosis, development, differentiation, and endocrine homeostasis, ${ }^{6}$ emerging evidence strongly suggests that the deregulation or dysfunction of miRs contributes to human carcinogenesis and cancer progression..$^{7-9}$ MiRs can function as either oncogenes or tumor suppressors according to the roles of their target genes. In terms of miR-206, it has been reported to be downregulated and exert tumor suppressive function in several malignancies such as breast cancer, ${ }^{10}$ lung cancer, ${ }^{11}$ gastric cancer, ${ }^{12}$ colorectal cancer, ${ }^{13}$ renal cell carcinoma, ${ }^{14}$ endometrioid adenocarcinoma, ${ }^{15}$ glioma and neuroblastoma, ${ }^{16}$ rhabdomyosarcoma, ${ }^{17}$ and osteosarcoma. ${ }^{18}$ In addition, downregulation of miR-206 was associated with tumor progression and worse prognosis. ${ }^{12,18-20}$ However, the role of miR-206 and its direct functional targets in human OSCC are still not completely clear.

Ras is the first human oncogene discovered by Shih and Weinberg in the early $1980 \mathrm{~s}^{21} \mathrm{~K}$-Ras is one of the three members of the Ras oncogene family. Activation of the $\mathrm{K}$-Ras oncogene has been implicated in the carcinogenesis of many human cancers, including OSCC, ${ }^{22}$ and downregulation of K-Ras could suppress cancer cell growth and increase chemosensitivity. ${ }^{23,24}$ Recently, several miRs reported to suppress K-Ras expression and function as tum suppressors. ${ }^{25-28}$ These findings support the r ance of miRs in regulation of K-Ras activity, by the pr ential regulatory effect of miR-206 on K-Ras pres has nor yet been confirmed.

The aim of this study was to examine mh 206 expression in OSCC tissues and cell line asing real-tim polymerase chain reaction (PCR). The as ciatio of miR-206 levels with clinicopathologic featur and $\mathrm{p}$ onosi vas also analyzed. Furthermore, the ef cts o miR- - on the proliferation, apoptosis, invasion an of OnCC cells were investigated. Finally, K as was identified as a direct target of miR-206 by luciferase røporter assay.

\section{Materials and methods}

\section{Tissue samples and cell lines}

One-hundred and nine pairs of primary OSCC and adjacent noncancerous tissues were collected from the Department of Oral and Maxillofacial Surgery, School and Hospital of Stomatology, Wenzhou Medical University (Wenzhou, People's Republic of China) between January 2005 and December 2008. All tissues were immediately frozen in liquid nitrogen and stored at $-80^{\circ} \mathrm{C}$ until analysis. None of the patients had undergone chemotherapy or radiotherapy before surgery. The patients' information is summarized in Table 1. All of the patients received follow-up. Overall survival was defined as the time from primary surgery to death of the patient or, for living patients, the date of last follow-up. This study was approved by the Research Ethics Committee of the hospital, and all patients gave informed consent.

Human OSCC cell lines (SCC-4, SCC-9, SCC-25, and Tca8113), and a human normal oral keratinocyte cell line were obtained from the Beijing Institute for Cancer Research (Beijing, People's Republic of China) and maintained in Dulbecco's Modified Eagle's Medium (DMEM) supplemented with Invitrogen ${ }^{\circledR} 10 \%$ fetal bovine serum (Thermo Fisher Sc ititno Waltham, MA, USA), $100 \mathrm{U} / \mathrm{mL}$ penicillin, anc $00 \mu \mathrm{g} / \mathrm{mL}$ treptomycin. All the cells were incubate at 370 in a b midified atmosphere with $5 \% \mathrm{CO}_{2}$.

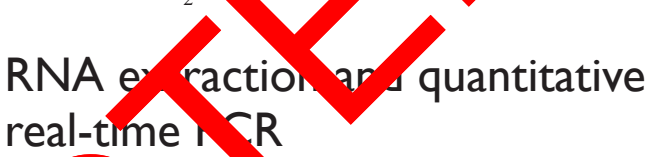

To ar RrJA was iso ted using the TRIzol ${ }^{\circledR}$ reagent (Thermo sher) acco ling to the manufacturer's instructions. Reverse tra scriptio reaction was carried out starting from $100 \mathrm{ng}$ of

abn I Correlation between microRNA-206 expression and different clinicopathological features in oral squamous cell carcinoma

\begin{tabular}{|c|c|c|c|c|}
\hline \multirow[t]{2}{*}{$\begin{array}{l}\text { Clinicopathological } \\
\text { features }\end{array}$} & \multirow[t]{2}{*}{$\mathbf{n}$} & \multicolumn{2}{|c|}{$\begin{array}{l}\text { MicroRNA-206 } \\
\text { expression }\end{array}$} & \multirow[t]{2}{*}{$P$-value } \\
\hline & & High & Low & \\
\hline \multicolumn{5}{|l|}{ Age } \\
\hline$<60$ years & 53 & $29(54.7 \%)$ & $24(45.3 \%)$ & 0.845 \\
\hline$\geq 60$ years & 56 & $26(46.4 \%)$ & $30(53.6 \%)$ & \\
\hline \multicolumn{5}{|l|}{ Sex } \\
\hline Male & 80 & 39 (48.8\%) & $4 \mathrm{I}(5 \mathrm{I} .2 \%)$ & 0.666 \\
\hline Female & 29 & $16(55.2 \%)$ & I 3 (44.8\%) & \\
\hline \multicolumn{5}{|l|}{ Histology/differentiation } \\
\hline Well/moderate & 75 & $37(49.3 \%)$ & $38(50.7 \%)$ & 0.837 \\
\hline Poor & 34 & I8 (52.9\%) & $16(47.1 \%)$ & \\
\hline \multicolumn{5}{|l|}{ T classification } \\
\hline $\mathrm{TI} / \mathrm{T} 2$ & 41 & $28(68.3 \%)$ & $13(31.7 \%)$ & 0.028 \\
\hline $\mathrm{T} 3 / \mathrm{T} 4$ & 68 & 27 (39.7\%) & $4 \mathrm{I}(60.3 \%)$ & \\
\hline \multicolumn{5}{|l|}{$\mathrm{N}$ classification } \\
\hline Positive & 39 & II (28.2\%) & 28 (7I.8\%) & 0.001 \\
\hline Negative & 70 & $44(62.9 \%)$ & $26(37.1 \%)$ & \\
\hline \multicolumn{5}{|l|}{ TNM stage } \\
\hline I/II & 31 & $25(80.6 \%)$ & $6(19.4 \%)$ & $<0.001$ \\
\hline III/IV & 78 & 30 (3I.4\%) & $48(68.6 \%)$ & \\
\hline
\end{tabular}

Note: Data is presented as $\mathrm{n}(\%)$.

Abbreviations: $\mathrm{N}$, spread to regional lymph nodes; $\mathrm{T}$, size and/or extent of the primary tumor; TNM, tumor node metastasis. 
total RNA using the looped primers. Real-time PCR was performed using the standard TaqMan ${ }^{\circledR}$ MicroRNA assays protocol on the Applied Biosystems ${ }^{\circledR} 7500$ real-time PCR detection system (Thermo Fisher), with cycling conditions of $95^{\circ} \mathrm{C}$ for 10 minutes followed by 40 cycles of $95^{\circ} \mathrm{C}$ for 15 seconds and $60^{\circ} \mathrm{C}$ for 60 seconds. U6 small nuclear RNA was used as an internal control. The RT primers were 5'-GCGCGTGAGCAGGCTGGAGAAATTAACCACGCGC-3' for miR-206 and 5'-TGGTGTCGTGGAGTCG-3' for U6. The PCR primers for mature miR-206 or U6 were designed as follows: miR-206 sense 5'-GGAATGTAAGGAAGTGTG-3' and miR-206 reverse 5'-GAGCAGGCTGGAGAA-3'; U6 sense 5'-CTCGCTTCGGCAGCACA-3' and U6 reverse 5'-AACGCTTCACGAATTTGCGT-3'. The threshold cycle was defined as the fractional cycle number at which the fluorescence passed the fixed threshold. Each sample was measured in triplicate, and the relative amount of miR-206 to U6 was calculated using the following equation:

$$
2^{-\Delta \mathrm{Ct}}
$$

where $\mathrm{Ct}$ is the threshold cycle and $\Delta \mathrm{Ct}$ is the threshold cycle of miR-206 minus the threshold cycle of U6 (ie, $\mathrm{Ct}_{\mathrm{miR}-206}-\mathrm{Ct}_{\mathrm{U} 6}$ ).

\section{Cell transfection}

For RNA transfection, the cells were seeded in of a 24-well plate and incubated overnight fected with either miR-206 mimics (Shan hai Pharm Co, Ltd, Shanghai, People's Republic China) on egative control (NC) RNA-oligonucleotides (Ge) Pharma) using Lipofectamine $^{\circledR} 2000$ (Therm sher) in aco dance with the manufacturer's procedo The cransfection efficiency of the miR-206 mimicaras c armed oy real-time PCR analysis.

3-(4,5-dimethylt, azol-2-yl)-2,5diphenyltetrazolium bromide (MTT) assay Cells were seeded into 96-well culture plates at a density of 2,000 cells in $200 \mu \mathrm{L} /$ well and incubated at $37^{\circ} \mathrm{C}$ after transfection. Then, $100 \mu \mathrm{L}$ of MTT solution $(0.5 \mathrm{mg} / \mathrm{mL}$; Sigma-Aldrich Co, St Louis, MO, USA) was added to each well, and the cells were incubated for another 4 hours. The medium was then replaced with $150 \mu \mathrm{L}$ of dimethyl sulfoxide. Spectrometric absorbance at $490 \mathrm{~nm}$ was measured using a microplate reader (BIO-RAD 680). Cell proliferation was assessed daily for four consecutive days, and the MTT assay was repeated three times.

\section{Detection of apoptosis by flow cytometry}

Apoptosis was detected by flow cytometric analysis. Briefly, the cells were washed and resuspended at a concentration of $1 \times 10^{6}$ cells $/ \mathrm{mL}$. Then, the cells were stained with Annexin V and propidium iodide, using the Annexin V Apoptosis Detection Kit (BD Biosciences, San Jose, CA, USA). After incubation at room temperature in the dark for 15 minutes, cell apoptosis was analyzed on a BD FACSCalibur ${ }^{\mathrm{TM}}$ (BD Biosciences).

\section{Transwell migration and invasion assays}

The migration and invasion assays were performed using 24-well Transwell ${ }^{\circledR}$ chambers ( $8 \mu \mathrm{m}$; Corning Incorporated, Corning, NY, USA). For the migration assay, tumor cells were resuspended in DMP and $10^{5}$ cells were seeded into the upper chambers. hen, $0.5 \mathrm{n}$. DMEM containing $10 \%$ FBS was add to the $b$ tom nambers. Following a 24-hour incubat 4 , cell on the upper surface of the membrane were cubbo off, an the migrated cells were fixed with $95 \%$ anol, sta with $0.1 \%$ crystal violet, and counted under right microscope (Olympus Corp., Tokyo, $\mathrm{Ja}$ an). The invasios assay protocol was similar to that of the gration a ay except that the upper chambers were first co red wit $1 \mathrm{mg} / \mathrm{mL}$ Matrigel ${ }^{\circledR}$ (Corning).

\section{underase reporter assays}

The pGL3 luciferase reporter vector (Promega Corporation, Fitchburg, WI, USA) was used for the construction of the pGL3-K-Ras and pGL3-K-Ras-mut vectors. The pGL3$\mathrm{K}$-Ras-mut vector was built with K-Ras that had undergone site-directed mutagenesis of the miR-206 target site using the QuikChange ${ }^{\circledR}$ Site-Directed Mutagenesis Kit (Agilent Technologies, Santa Clara, CA, USA). For the luciferase reporter assay, cells were cultured in 24-well plates and transfected with the plasmids and miR-206 mimics using Lipofectamine 2000. Twenty-four hours after transfection, luciferase activity was measured using the Dual-Luciferase ${ }^{\circledR}$ Reporter Assay System (Promega). Firefly luciferase activity was normalized to renilla luciferase activity for each transfected well.

\section{Western blot analysis}

Protein lysates were separated by $10 \%$ sodium dodecyl sulfate polyacrylamide gel electrophoresis and transferred to the nitrocellulose membrane. After blocking, the membranes were incubated with purified rabbit anti-K-Ras antisera at $4^{\circ} \mathrm{C}$ overnight. The next day, the membranes were washed with phosphate-buffered saline and then incubated with 
peroxidase-conjugated goat anti-rabbit immunoglobulin $\mathrm{G}$ (Santa Cruz Biotechnology, Texas, USA). Immunodetection was conducted with Pierce ${ }^{\circledR}$ ECL chemiluminescence reagents (Thermo Fisher) and exposed on an X-ray film. $\beta$-actin was used as an internal reference for relative quantification.

\section{Statistics}

All statistical analyses were carried out using $\mathrm{SPSS}^{\circledR}$ 16.0 software package (SPSS Inc., Chicago, IL, USA). Data were presented as mean \pm standard deviation (SD). Differences between groups were analyzed using Student's $t$-test or the chi-square test. Relationships between miR-206 expression and K-Ras protein levels were explored by Pearson's correlation analysis. Survival curves were constructed with the
Kaplan-Meier method and compared by log-rank tests. To evaluate independent prognostic factors associated with survival, a multivariate Cox proportional hazards regression analysis was used. $P<0.05$ was considered to be statistically significant.

\section{Results \\ Decreased expression of miR-206 in OSCC and its correlation with K-Ras levels}

The expression levels of miR-206 in OSCC tissues, corresponding noncancerous samples, human OSCC cell lines SCC-4, SCC-9, SCC-25, and Tca8113, and human normal oral keratinocyte cells were detected by quantitative real-time PCR and normalized to U6 small nuclear RNA. As

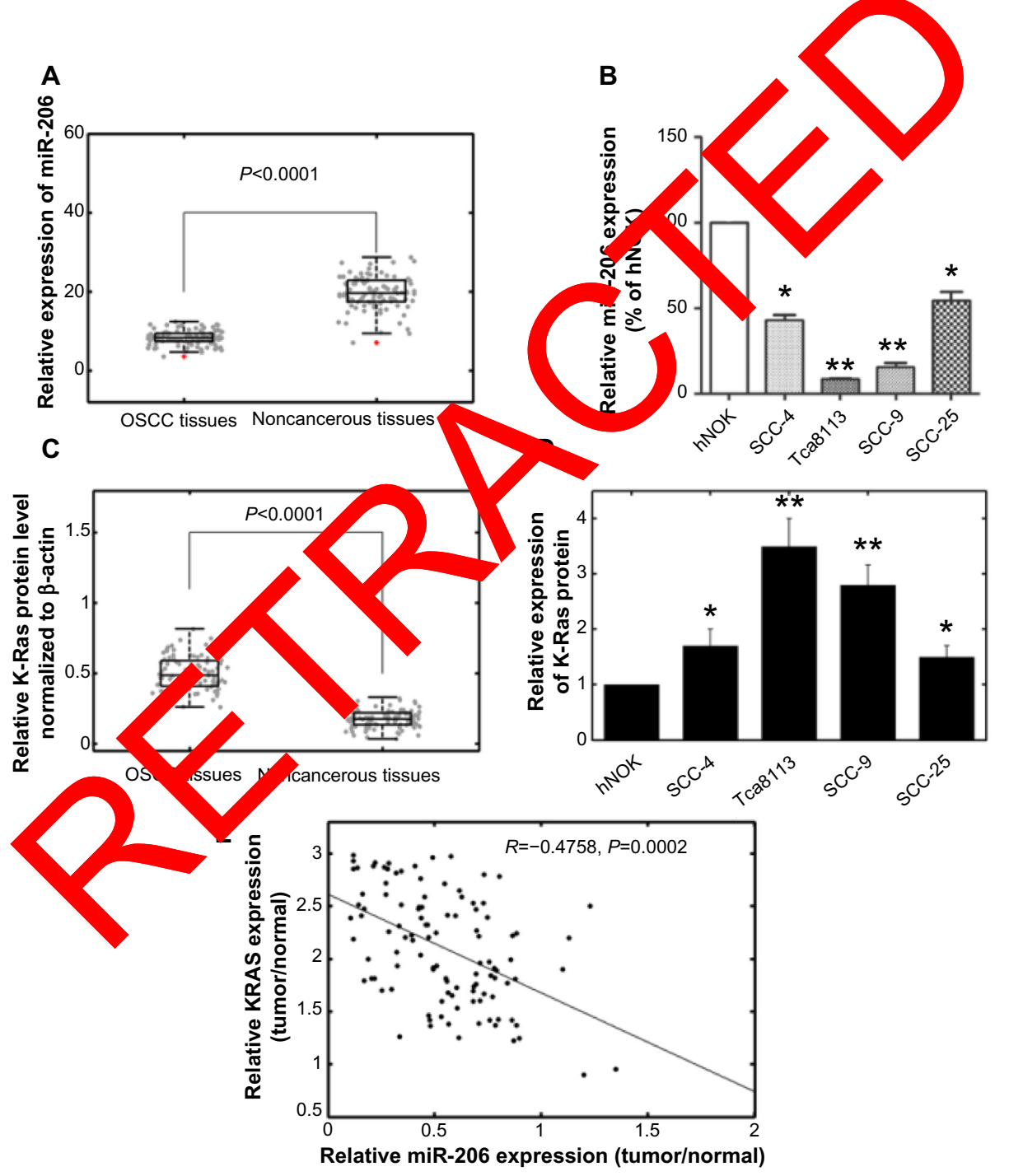

Figure I Expression of miR-206 and K-Ras in OSCC tissues and cell lines.

Notes: (A) MiR-206 expression was significantly lower in OSCC tissues than in the corresponding noncancerous tissues. MiR-206 expression levels were calculated by the $2^{-\Delta C \mathrm{t}}$ method and normalized to U6 small nuclear RNA. The red points denote outliers. (B) MiR-206 expression was downregulated in OSCC cell lines SCC-4, SCC-9, SCC-25, and Tca8II3 compared to hNOK cells. (C) Relative K-Ras protein levels in OSCC and corresponding noncancerous tissues. K-Ras protein levels were measured by Western blot analysis and normalized to $\beta$-actin. (D) K-Ras protein levels in OSCC cells were higher than in hNOK cells. (E) The inverse correlation of K-Ras protein levels with miR-206 expression was examined by Pearson's correlation analysis. $* p<0.05 ; * * P<0.01$.

Abbreviations: $\Delta \mathrm{Ct}$, threshold cycle of miR-206 minus the threshold cycle of U6; hNOK, human normal oral keratinocyte; miR-206, microRNA-206; OSCC, oral squamous cell carcinoma. 
in Figure 1A, the results showed that the expression levels of miR-206 were significantly lower in OSCC specimens (mean \pm SD 8.2 \pm 2.1 ) than those in the corresponding adjacent noncancerous tissues (mean \pm SD $19.4 \pm 4.1 ; P<0.001$ ). The miR-206 expression in four OSCC cell lines was also clearly downregulated (Figure 1B). The Tca8113 cell line, which possessed the lowest levels of miR-206 expression among all tested cell lines, was selected for further studies.

K-Ras protein levels were detected by using Western blot analysis in clinical specimens and cell lines. The results showed that K-Ras protein levels in tumor samples were higher than in the adjacent normal tissues $(P<0.001$; Figure 1C). K-Ras levels in OSCC cells were also higher than in human normal oral keratinocyte cells (Figure 1D). In addition, an obvious inverse correlation $(R=-0.4758 ; P=0.0002)$ was obtained between K-Ras levels and miR-206 expression in OSCC tumor tissues (Figure 1E).

\section{MiR-206 expression and clinicopathologic features in OSCC}

The associations of miR-206 expression with various clinicopathological parameters of OSCC tissues are summarized in Table 1. Using the median miR-206 expression in all 109 OSCC patients as a cutoff, the patients were divided into a high miR-206 expression group and low miR-206 express group. As shown in Table 1, low expression of miR-206 wa significantly correlated with advanced tumor no met tasis (TNM) stage $(P<0.001)$, advanced T classific ions $P$ and/or extent of the tumor; $P=0.028$ ), an positiv classification (ie, spread to regional lymph $\mathrm{n}$,es, $\mathrm{Q}=0.001$ ). Jo significant difference was observed b ween mik 06 expression and patients' age, sex, and tur or diff 'entiation.

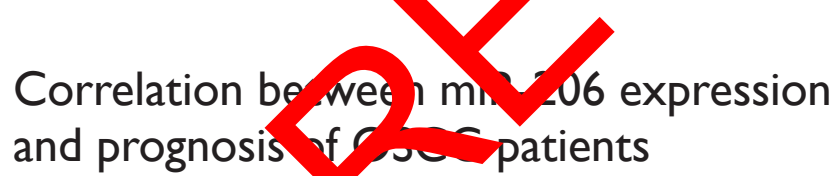

It was then evaluated hether miR-206 expression had prognostic potential for onvall survival of OSCC patients. Using the Kaplan-Meier method and log-rank test, the overall survival of patients with low miR-206 expression was significantly shorter than in those with high miR-206 expression $(P<0.001$; Figure 2$)$. The survival benefits were also found in those with early $\mathrm{T}$ classification $(P=0.008)$, negative $\mathrm{N}$ classification ( $P=0.006)$, and early TNM stage $(P<0.001$; Table 2).

Multivariate Cox regression analysis enrolling the abovementioned significant parameters revealed that miR-206 expression (relative risk [RR] 6.245; $P=0.015$ ), $\mathrm{T}$ classification (RR 3.655; $P=0.032$ ), $\mathrm{N}$ classification

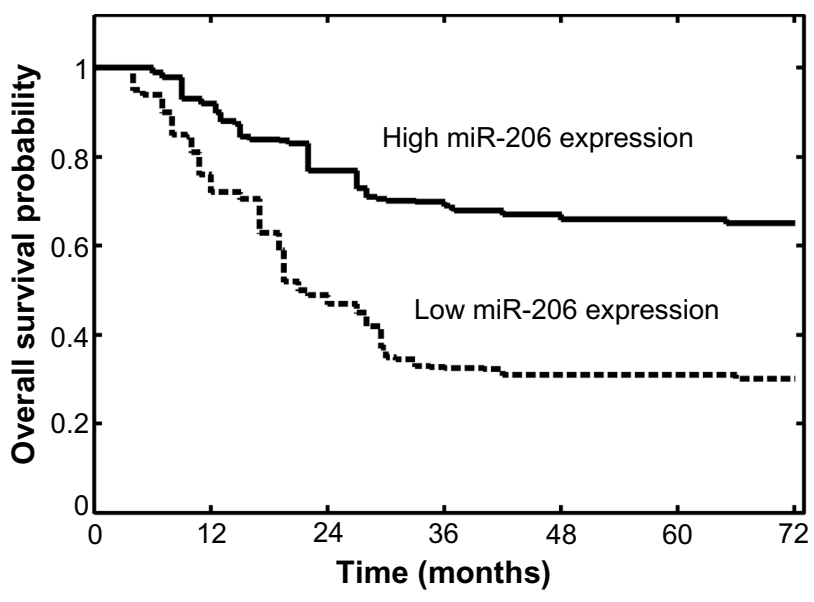

Figure 2 Overall survival curves for the two groups defined by low and high expression of miR-206 in patients with oral squamous cell carcinoma. Low miR-206 expression levels were significantly ass poor outcome $(P<0.00 \mathrm{I}$, logrank test).

Abbreviation: miR-206, microRN 206.

(RR 4.278; $P=0$ 2), an TNM ge (RR 8.379; $P=0.008)$ were indepen nt $_{\mathrm{N}}$, nostic arkers for overall survival of OSCC p s (Table

\section{Esects of min 206 on the proliferation, boptosi, invasion, and migration or ca8/ 3 cells}

the biological role of miR-206 in Tca8113 cells was also assessed. As shown in Figure 3A, the expression level of miR-206 in transfected cells of miR-206 mimics was significantly higher compared with noncancerous

Table 2 Univariate and multivariate analysis of overall survival in 109 patients with oral squamous cell carcinoma

\begin{tabular}{|c|c|c|c|}
\hline Variables & $\begin{array}{l}\text { Univariate } \\
\text { log-rank } \\
\text { test } \\
(P \text {-value })\end{array}$ & $\begin{array}{l}\text { Cox } \\
\text { multivariable } \\
\text { analysis } \\
\text { ( } P \text {-value) }\end{array}$ & $\begin{array}{l}\text { Relative } \\
\text { risk }\end{array}$ \\
\hline \multicolumn{4}{|l|}{ Age at diagnosis } \\
\hline$<60$ versus $\geq 60$ years & 0.32 & - & - \\
\hline \multicolumn{4}{|l|}{ Sex } \\
\hline Male versus female & 0.45 & - & - \\
\hline \multicolumn{4}{|l|}{ Histology/differentiation } \\
\hline $\begin{array}{l}\text { Well/moderate } \\
\text { versus poor }\end{array}$ & 0.26 & - & - \\
\hline \multicolumn{4}{|l|}{ T classification } \\
\hline $\mathrm{TI} / \mathrm{T} 2$ versus $\mathrm{T} 3 / \mathrm{T} 4$ & 0.008 & 0.032 & 3.655 \\
\hline \multicolumn{4}{|l|}{$N$ classification } \\
\hline Positive versus negative & 0.006 & 0.022 & 4.278 \\
\hline \multicolumn{4}{|l|}{ TNM stage } \\
\hline I/II versus III/IV & $<0.001$ & 0.008 & 8.379 \\
\hline \multicolumn{4}{|l|}{ MicroRNA-206 expression } \\
\hline High versus low & $<0.001$ & 0.015 & 6.245 \\
\hline
\end{tabular}

Abbreviations: $\mathrm{N}$, spread to regional lymph nodes; $\mathrm{T}$, size and/or extent of the primary tumor; TNM, tumor node metastasis. 
A

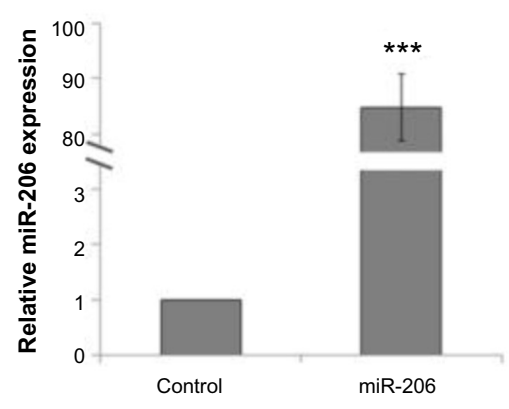

C

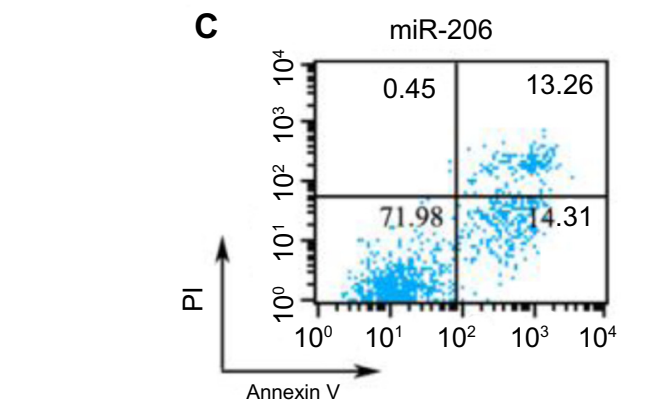

D

miR-206 mimics

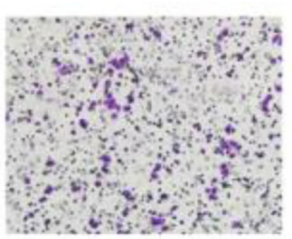

E
B

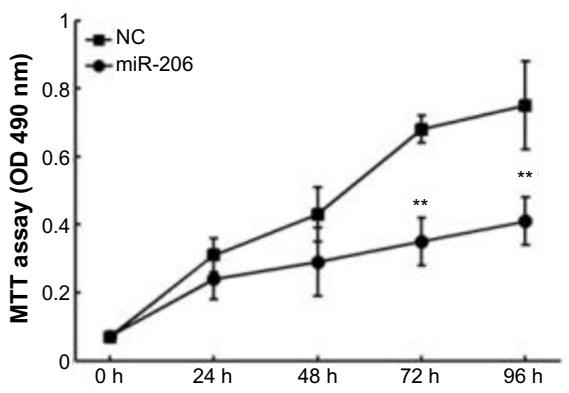

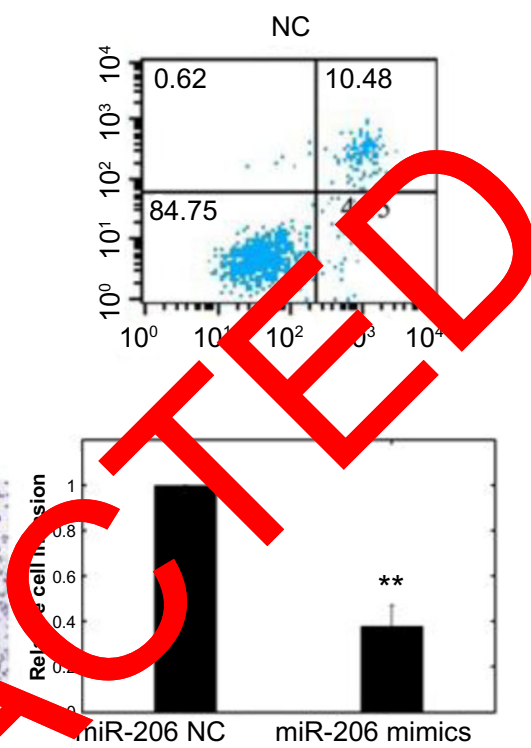

miR-206 mimics
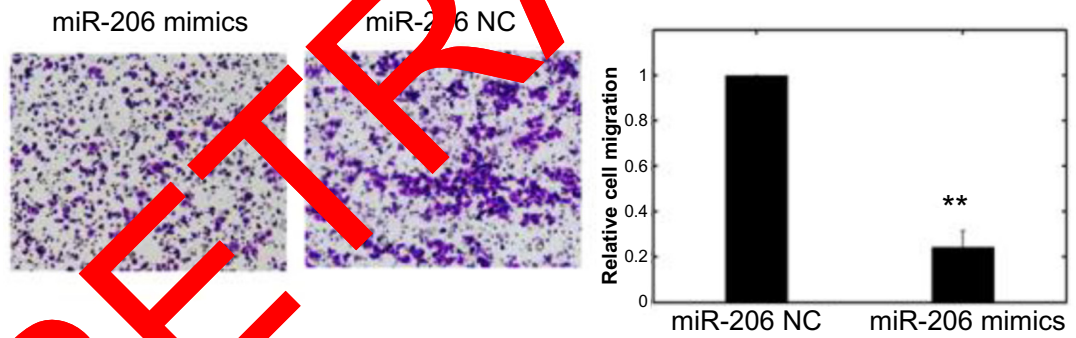

Figure 3 Effects of transfer on of mip 206 mimi cell proliferation, apoptosis, invasion, and migration of Tca8 I I 3 cells.

Notes: (A) The expressí evel cells of miR-206 mimics was significantly higher compared with NC transfected cells. Quantitative real-time polymerase chain reaction wa to detect the expression of miR-206. U6 RNA was used as an internal control. (B) Cell proliferation was measured by MTT assays in Tca8II 3 cells transfected with iR-206 mimics or negative control. The data represent the mean \pm standard deviation of the experiments performed in triplicate. (C) Apoptosis of Tca8II 3 cells was deto d by flow cytometric analysis after transfection with miR-206 mimics or negative control. (D and E) MiR-206 suppressed Tca8II3 cell invasion and migration in vitro. The invasion and migration assays showed that the number of invaded or migrated cells was significantly lower in the miR-206-transfected group than in the NC-transfected group. $* * P<0.01$; $* * * P<0.00 \mathrm{I}$.

Abbreviations: miR-206, microRNA-206; MTT, 3-(4,5-dimethylthiazol-2-yl)-2,5-diphenyltetrazolium bromide; NC, noncancerous; OD, optical density; PI, propidium iodide.

transfected cells $(P<0.001)$. MTT assay showed that cell proliferation was significantly impaired after miR-206 mimics transfection (Figure 3B). Promoted cell apoptosis in transfected cells of miR-206 mimics was also observed (Figure 3C).

Cell invasion is a significant aspect of cancer progression and involves the migration of tumor cells into contiguous tissues and the dissolution of extracellular matrix proteins. Transwell invasion and migration assays were performed to investigate whether miR-206 had a direct influence on Tca8113 cell migration and invasion. As shown in Figure 3D and E, upregulation of miR-206 impeded cell invasion/migration compared with the control. 


\section{K-Ras is the target gene of miR-206}

Using the algorithms for target gene prediction, K-Ras was identified as one of the potential targets of miR-206. The predicted binding of miR-206 with K-Ras 3' untranslated region is illustrated in Figure 4A. To further confirm that K-Ras is the direct target of miR-206 in OSCC, miR-206 mimics were transfected into Tca8113 cells and it was found that miR-206 mimics significantly reduced $\mathrm{K}$-Ras protein levels in these cells (Figure 4B). Then, pGL3-K-Ras and pGL3-K-Rasmut plasmids were created. The reporter assay revealed that transfection of miR-206 mimics triggered a marked decrease of luciferase activity of the pGL3-K-Ras plasmid in Tca8113 cells without change in the luciferase activity of pGL3-KRas-mut (Figure 4C). These data indicate that K-Ras is a direct target of miR-206 in OSCC.

\section{Discussion}

Dysregulation of miRs has been demonstrated to be involved in tumorigenesis and progression in various types of tumor; however, elucidation of their potential roles in OSCC remains in the early stage of development. In this study, it was found that miR-206 was downregulated in OSCC cell lines and primary tumor samples. Decreased miR-206 expression was significantly correlated with aggressive clinicopathological features and poor survival. Moreover, transfect of miR-206 mimics in Tca8113 cells was able to redu cell proliferation, invasion, and migration and promote cell apoptosis. Finally, K-Ras was identified as a direct target of miR-206. To the authors' knowledge, this study reported the prognostic significance of miR-206 in OSCC and confirmed K-Ras as a functional target of miR-206 for the first time.

Previous research reported dysregulated miR-206 expression and its tumor suppressive function in many human malignancies. In vitro, ectopic miR-206 expression inhibits cell growth and induces apoptosis in breast cancer, ${ }^{29}$ lung cancer, ${ }^{11}$ gastric cancer, ${ }^{12}$ glioma and neuroblastoma, ${ }^{16}$ rhabdomyosarcoma, ${ }^{17}$ and endometrial endometrioid carcinoma cells. ${ }^{15}$ Upregulation of miR-206 also reduces cell invasion and migration in lung cancer, ${ }^{11}$ rhabdomyosarcoma, ${ }^{17}$ and endometrial endometrioid carcinoma cells. ${ }^{15}$ In vivo, Bao et al revealed decreas $\mathrm{mr} 206$ expression and its correlation with a worse se, poor $\mathrm{h}$ tological differentiation, and metastasis 1 patio s with osteosarcoma. ${ }^{18}$ Yang et al reported that $1 \mathrm{R}-2 \varnothing$ down sulation occurs more frequently in gas ic ca patien with lymph node metastasis, along wit presen renous invasion, hematogenous recurrence, an advanced tumor stage. ${ }^{19}$ Moreover, lower ex csson of mik 06 indicated worse prognosis of patients ffering ga ric cancer or colorectal carcinoma. ${ }^{19,20}$ In xenoth splanter models, miR-206-treated nude mice showed sman nor sizes and lower tumor weights compared with atrol group. ${ }^{12,30}$ Taken together, these findings suggest

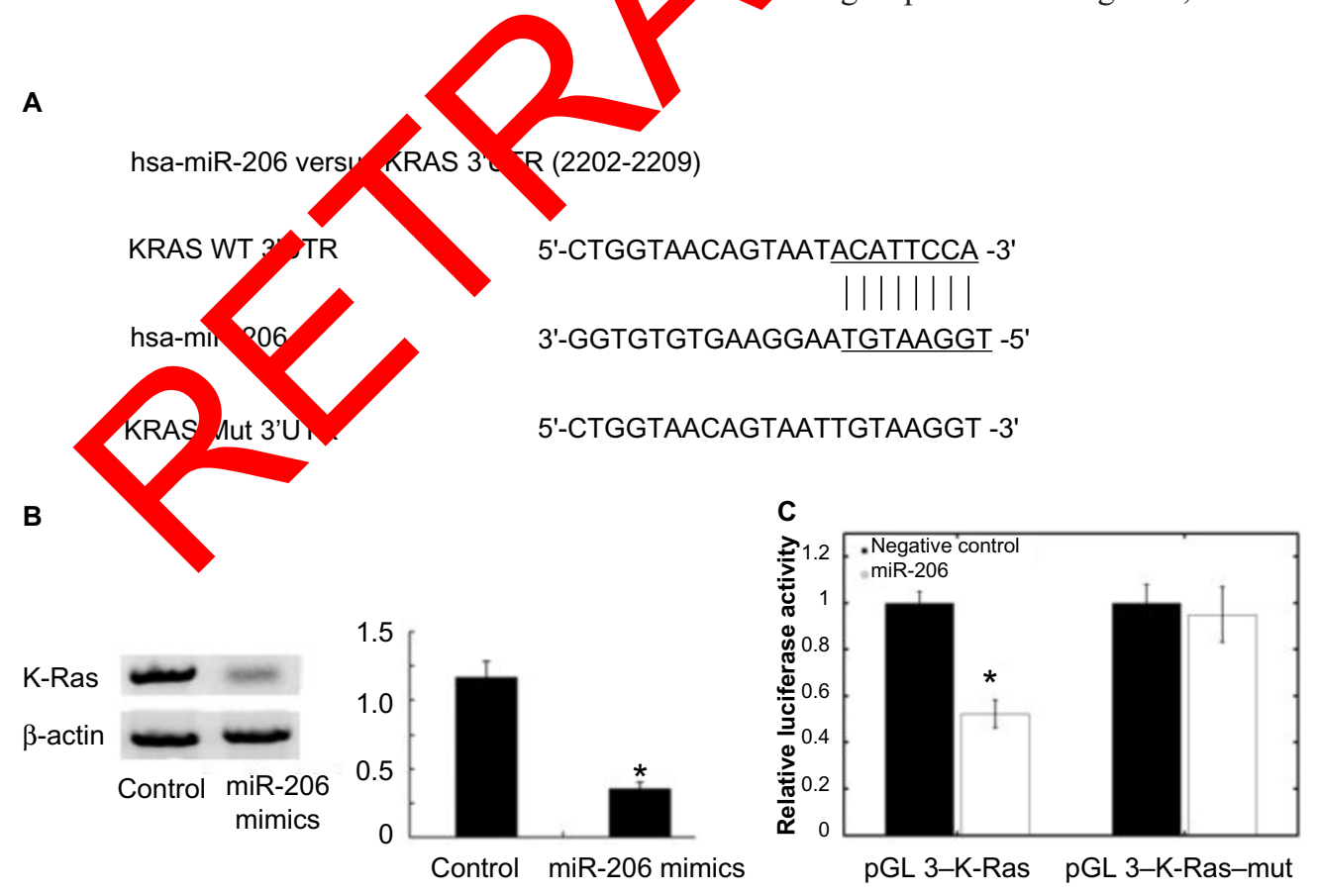

Figure 4 K-Ras is a direct target of miR-206. (A) MiR-206 binding sites in K-Ras 3' UTR. K-Ras-mut indicates the K-Ras 3' UTR with mutation in miR-206 binding sites. (B) The Western blot showed that transfection of miR-206 decreased K-Ras protein expression. (C) Relative luciferase assay comparing the pGL3-K-Ras and PGL3-K-Ras-mut vectors in Tca8I I 3 cells. Firefly luciferase activity was normalized to renilla luciferase activity. $* P<0.05$. Abbreviations: hsa-miR-206, human microRNA-206; UTR, untranslated region; WT, wild type; Mut, mutation. 
that miR-206 might play an important role not only in tumor initiation and progression but also in the molecular targeted therapy of human malignancies.

It is now clear that miRNAs execute their oncogenic or tumor suppressor functions by regulating the expression of target genes. ${ }^{31}$ With regard to miR-206, several targets have been reported in recent research including CCND2, ${ }^{12} \mathrm{Otx} 2,{ }^{16} \mathrm{MET},{ }^{30}$ Pax $7,{ }^{32}$ NOTCH $3,{ }^{33}$ ER $\alpha,{ }^{34}$ and VEGF. ${ }^{35}$ Ras is involved in the execution of important steps in tumorigenesis and miR-induced $\mathrm{K}$-Ras dysregulation is frequently observed in human cancers. MiR-18a* repression upregulated K-Ras expression, increased cell proliferation, and promoted anchorage-independent growth in soft agar of human squamous carcinoma A431 cells, colon adenocarcinoma HT-29 cells, and fetal hepatic WRL-68 cells. ${ }^{36}$ MiR-96 decreased pancreatic cancer cell invasion and migration and slowed tumor growth in a manner associated with K-Ras downregulation. ${ }^{26}$ MiR-143 suppressed K-Ras and functioned as a tumor suppressor in colorectal cancer. ${ }^{27}$ In OSCC, miR-181a reduced cell proliferation by depressing K-Ras. ${ }^{25}$ The current study also demonstrated that K-Ras is a functional target of miR-206 in OSCC. The overexpression of miR-206 in Tca8113 cells decreased K-Ras protein levels. After cotransfection of the pGL3 reporter vectors and miR-206 mimics, upregulation of miR-206 resulted in a significant decrease in the luciferase activity of the wild-type pGL3-K-Ras plasi whereas mutation of the miR-206 binding site blocked th effect. However, there is no "one-to-one" connect to ween miRs and target messenger RNAs. An averag hiR co Lhave more than 100 targets. ${ }^{37}$ Conversely, several ciRs converge on a single transcript target. ${ }^{38}$ Previoy udies hav proven that some other target genes of miR-206, st as VEGF and Notch, ${ }^{39,40}$ also modulate OSCC pathogenesis. - Nerefore, the potential regulatory circuitry a orded y miR-206 is enormous, and the accurate mech ns ow how 106 influences OSCC progression $\mathrm{n}$ d fur er clas ation.

There are some h ito ons is work. First, the clinical part was a retrospectiv study, and the tumor sample size was relatively small. Second, the effects of miR-206 on the biological behavior of OSCC cells were only observed in one cell line, although Tca8113 cells possessed the lowest miR-206 expression among all tested cell lines in this study. Further experimental validation using a large number of tumor samples and more cell lines will be performed in the future.

\section{Conclusion}

The results revealed that miR-206 was downregulated in OSCC cell lines and clinical samples. Restored miR-206 expression in Tca8113 cells exhibited antitumor effects in vitro. In addition, K-Ras was confirmed as a direct target of miR-206. These findings indicate that miR-206 may act as a tumor suppressor in OSCC and could serve as a novel therapeutic agent for miR-based therapy.

\section{Disclosure}

The authors report no conflicts of interest in this work.

\section{References}

1. Sharma P, Saxena S, Aggarwal P. Trends in the epidemiology of oral squamous cell carcinoma in Western UP: an institutional study. Indian J Dent Res. 2010;21(3):316-319.

2. Massano J, Regateiro FS, Januario G, Ferreira A. Oral squamous cell carcinoma: review of prognostic and predictive factors. Oral Surg Oral Med Oral Pathol Oral Radiol Ep 2006;102(1):67-76.

3. Rodrigo JP, Lequerica-Fern dez P, ado P, Allonca E, GarciaPedrero JM, de Vicente Clinical s nificance of annexin A2 downregulation in $9 \mathrm{sq}$ nous cel carcinoma. Head Neck. 2011;33(12):1708

4. Lin YT, Chuang Che Che $\mathrm{CH}$, et $\mathrm{Clinical}$ significance of erythropoietin recerto $\mathrm{vp}^{\prime}$ sion in sal squamous cell carcinoma. BMC Cancer. $2^{\circ}$

5. Osman icroRNAs h and disease-basic science and clinical appliadions. in Lab. 2012;58(5-6):393-402.

6. P DP. Mio RNAs: genomics, biogenesis, mechanism, and runction. Cell. 200, 1 16(2):281-297.

Zhang B, n X, Cobb GP, Anderson TA. MicroRNAs as oncogenes and tumor ippressors. Dev Biol. 2007;302(1):1-12.

8. ieckma KP, Spiekermann M, Balks T, et al. MicroRNAs miR-371-3 in sorum as diagnostic tools in the management of testicular germ cell mours. Br J Cancer. 2012;107(10):1754-1760.

9. Takahashi M, Cuatrecasas M, Balaguer F, et al. The clinical significance of miR-148a as a predictive biomarker in patients with advanced colorectal cancer. PLoS One. 2012;7(10):e46684.

10. Iorio MV, Ferracin M, Liu CG, et al. MicroRNA gene expression deregulation in human breast cancer. Cancer Res. 2005;65(16): 7065-7070.

11. Wang X, Ling C, Bai Y, Zhao J. MicroRNA-206 is associated with invasion and metastasis of lung cancer. Anat Rec (Hoboken). 2011;294(1): 88-92.

12. Zhang L, Liu X, Jin H, et al. MiR-206 inhibits gastric cancer proliferation in part by repressing cyclinD2. Cancer Lett. 2013;332(1): 94-101.

13. Parasramka MA, Dashwood WM, Wang R, et al. A role for lowabundance miRNAs in colon cancer: the miR-206/Kruppel-like factor 4 (KLF4) axis. Clin Epigenetics. 2012;4(1):16.

14. Zhou L, Chen J, Li Z, et al. Integrated profiling of microRNAs and mRNAs: microRNAs located on Xq27.3 associate with clear cell renal cell carcinoma. PLoS One. 2010;5(12):e15224.

15. Chen X, Yan Q, Li S, et al. Expression of the tumor suppressor miR-206 is associated with cellular proliferative inhibition and impairs invasion in ER $\alpha$-positive endometrioid adenocarcinoma. Cancer Lett. 2012;314(1):41-53.

16. Wang R, Hu Y, Song G, et al. MiR-206 regulates neural cells proliferation and apoptosis via Otx2. Cell Physiol Biochem. 2012;29(3-4):381-390.

17. Missiaglia E, Shepherd CJ, Patel S, et al. MicroRNA-206 expression levels correlate with clinical behaviour of rhabdomyosarcomas. $\mathrm{Br} J$ Cancer. 2010;102(12):1769-1777.

18. Bao YP, Yi Y, Peng LL, et al. Roles of microRNA-206 in osteosarcoma pathogenesis and progression. Asian Pac J Cancer Prev. 2013;14(6):3751-3755. 
19. Yang Q, Zhang C, Huang B, et al. Downregulation of microRNA-206 is a potent prognostic marker for patients with gastric cancer. Eur $J$ Gastroenterol Hepatol. 2013;25(8):953-957.

20. Vickers MM, Bar J, Gorn-Hondermann I, et al. Stage-dependent differential expression of microRNAs in colorectal cancer: potential role as markers of metastatic disease. Clin Exp Metastasis. 2012;29(2): $123-132$.

21. Shih C, Weinberg RA. Isolation of a transforming sequence from a human bladder carcinoma cell line. Cell. 1982;29(1):161-169.

22. Caulin C, Nguyen T, Longley MA, Zhou Z, Wang XJ, Roop DR. Inducible activation of oncogenic K-ras results in tumor formation in the oral cavity. Cancer Res. 2004;64(15):5054-5058.

23. Funato T, Ishii T, Kambe M, Scanlon KJ, Sasaki T. Anti-K-ras ribozyme induces growth inhibition and increased chemosensitivity in human colon cancer cells. Cancer Gene Ther. 2000;7(3):495-500.

24. Fleming JB, Shen GL, Holloway SE, Davis M, Brekken RA. Molecular consequences of silencing mutant K-ras in pancreatic cancer cells: justification for K-ras-directed therapy. Mol Cancer Res. 2005;3(7):413-423.

25. Shin KH, Bae SD, Hong HS, Kim RH, Kang MK, Park NH. MiR-181a shows tumor suppressive effect against oral squamous cell carcinoma cells by downregulating K-ras. Biochem Biophys Res Commun. 2011;404(4):896-902.

26. Yu S, Lu Z, Liu C, et al. MiRNA-96 suppresses KRAS and functions as a tumor suppressor gene in pancreatic cancer. Cancer Res. 2010;70(14):6015-6025.

27. Chen X, Guo X, Zhang H, et al. Role of miR-143 targeting KRAS in colorectal tumorigenesis. Oncogene. 2009;28(10):1385-1392.

28. Zhao WG, Yu SN, Lu ZH, Ma YH, Gu YM, Chen J. The miR-217 microRNA functions as a potential tumor suppressor in pancreatic ductal adenocarcinoma by targeting KRAS. Carcinogenesis. 2010;31(10):1726-1733.

29. Leivonen SK, Makela R, Ostling P, et al. Protein lysate microarray analysis to identify microRNAs regulating estrogen receptor signaling in breast cancer cell lines. Oncogene. 2009;28(44):3926-3936.
30. Taulli R, Bersani F, Foglizzo V, et al. The muscle-specific microRNA miR-206 blocks human rhabdomyosarcoma growth in xenotransplanted mice by promoting myogenic differentiation. J Clin Invest. 2009;119(8):2366-2378.

31. Liu GF, Tang D, Li P, et al. S-1-based combination therapy vs S-1 monotherapy in advanced gastric cancer: a meta-analysis. World $J$ Gastroenterol. 2014;20(1):310-318.

32. Dey BK, Gagan J, Dutta A. MiR-206 and -486 induce myoblast differentiation by downregulating Pax7. Mol Cell Biol. 2011;31(1):203-214.

33. Song G, Zhang Y, Wang L. MicroRNA-206 targets notch3, activates apoptosis, and inhibits tumor cell migration and focus formation. J Biol Chem. 2009;284(46):31921-31927.

34. Kondo N, Toyama T, Sugiura H, Fujii Y, Yamashita H. MiR-206 expression is down-regulated in estrogen receptor $\alpha$-positive human breast cancer. Cancer Res. 2008;68(13):5004-5008.

35. Zhang T, Liu M, Wang C, Lin C, Sun Y, Jin D. Down-regulation of miR-206 promotes proliferation and invasion of laryngeal cancer by regulating VEGF expression. Anticancer Res. 2011;31(11):3859-3863.

36. Tsang WP, Kwok TT. The miR-18a* microRNA functions as a potential tumor suppressor by ing on K-Ras. Carcinogenesis. 2009;30(6):953-959.

37. Brennecke J, Stark A, Russ RB, Cohen S Principles of microRNAtarget recognition. $P$

38. Krek A, Grun D, y $\mathrm{MN}$, et on Cor natorial microRNA target predictions. Nat enet. $20,37(5),-500$.

39. MargaritescunC, icj , Simiorescu C, et al. VEGF and VEGFRs expressior oral squ nous ce carcinoma. Rom J Morphol Embryol. $2009 ;$

40. Zhang T, Lis L, Liang Y, et al. [The expression and significance Notch sis ling pathway molecules in tongue squamous cell carcinoma]. Hua X.Kou Qiang Yi Xue Za Zhi. 2013;31(3):303-309. Chinese.

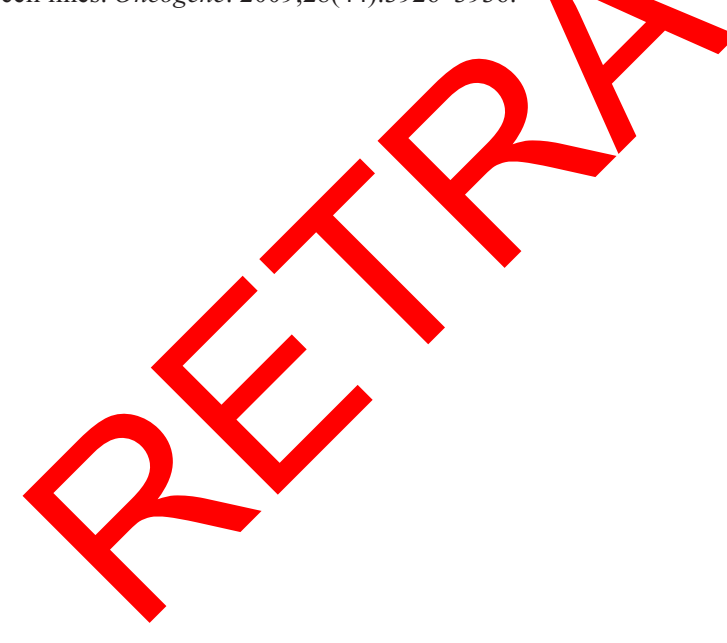

OncoTargets and Therapy

Dovepress

\section{Publish your work in this journal}

OncoTargets and Therapy is an international, peer-reviewed, open access journal focusing on the pathological basis of all cancers, potential targets for therapy and treatment protocols employed to improve the management of cancer patients. The journal also focuses on the impact of management programs and new therapeutic agents and protocols on patient perspectives such as quality of life, adherence and satisfaction. The manuscript management system is completely online and includes a very quick and fair peer-review system, which is all easy to use. Visit http://www.dovepress.com/testimonials.php to read real quotes from published authors. 